This item was submitted to Loughborough's Research Repository by the author.

Items in Figshare are protected by copyright, with all rights reserved, unless otherwise indicated.

\title{
Interculturalism versus multiculturalism - the Cantle-Modood debate
}

PLEASE CITE THE PUBLISHED VERSION

http://dx.doi.org/10.1177/1468796815604558

PUBLISHER

Sage / ( ) The Authors

VERSION

AM (Accepted Manuscript)

PUBLISHER STATEMENT

This work is made available according to the conditions of the Creative Commons Attribution-NonCommercialNoDerivatives 4.0 International (CC BY-NC-ND 4.0) licence. Full details of this licence are available at: https://creativecommons.org/licenses/by-nc-nd/4.0/

\section{LICENCE}

CC BY-NC-ND 4.0

\section{REPOSITORY RECORD}

Antonsich, Marco. 2019. "Interculturalism Versus Multiculturalism - the Cantle-modood Debate". figshare. https://hdl.handle.net/2134/21433. 
To be printed in Ethnicities DOI: 10.1177/1468796815604558

\section{Interculturalism vs Multiculturalism - The Cantle-Modood Debate}

\section{Marco Antonsich}

On 25 March 2015, the Migration, Identity and the State (MIS) Research Cluster within the Human Geography Research Group at Loughborough University invited Ted Cantle and Tariq Modood to discuss a central question of contemporary societies: 'how to live together in diversity'. As societies are becoming increasingly diverse, the question is indeed no longer how to live with, but in diversity (Antonsich, 2014; Antonsich \& Matejskova, 2015). This is not only a shift in prepositions, but a conceptual shift which aims to convey two ideas. First, diversity is not only something 'carried' by minorities which leaves the majority group untouched; but in a future which demographic projections anticipate as even more diverse, diversity itself might become the mainstream. Second, and ensuing from this demographic scenario, to live with presupposes tolerance as the answer to the above question. Yet, tolerance itself is deeply problematic, being indeed imbued with an uneven power relation (Brown, 2009), as "tolerance always presupposes a control over what is tolerated" (Hage, 2000: 89). Using in is therefore a tactical move to open up the terrain for a more thorough exploration of diversity and the related urge for governing diverse societies (Matejskova \& Antonsich, 2015).

The 'Cantle-Modood debate' presented here, with the additional commentary by lacovino who expands this debate overseas, by bringing the case of Quebec in, intervenes exactly on this question and it does so by juxtaposing two approaches: multiculturalism and interculturalism. The key point by Cantle is that multiculturalism got it wrong because it has worked with an idea of culture as temporally and spatially fixed, while the world has long pointed to complex and multiple patterns of cultural formations. Interculturalism, for Cantle, promises exactly to attend to this complexity, beyond the communitarian approach of multiculturalism. In his intervention, Modood defends instead multiculturalism both as a theory and as a series of policies, but he also acknowledges that multiculturalism has something to learn from certain criticisms made by interculturalism. In no way, though, should the former be considered as an alternative policy or philosophy to the latter, as for Modood interculturalism is merely a variant of multiculturalism. In his commentary, lacovino reads both interventions against the experience of Quebecan interculturalism, highlighting the importance of the national context to fully capture the variations in the British and Quebecan models. The hope is that together these three interventions could offer a valuable contribution to keep thinking about how to live together in diversity. ${ }^{1}$

\section{References}

Antonsich M (2014) Living together in diversity. A journey from scholarly views to people's voices and back. Bollettino della Società Geografica Italiana, 13(7), 317-337.

Antonsich M \& Matejskova T (2015). Immigration societies and the question of 'the national'. Ethnicities, 0(0), 1-14.

Brown W (2009) Regulating aversion. Princeton: Princeton University Press.

Hage $\mathrm{G}$ (2000) White nation. London: Routledge.

Matejskova, T., \& Antonsich, M. (Eds.). (2015). Governing through diversity. Basingstoke: Palgrave.

Meer N, Modood T and Zapata-Barrero R. (forthcoming, 2015/16) Interculturalism and Multiculturalism. Edinburgh: Edinburgh University Press.

\footnotetext{
${ }^{1}$ The three authors further develop their understanding of interculturalism and multiculturalism in Meer, Modood and Zapata-Barrero, 2016.
} 


\section{Interculturalism: 'Learning to Live in Diversity'}

\section{Ted Cantle}

\section{Introduction}

The era of multiculturalism had no definite starting point, but had its genesis in the 1960 s and ' 70 s, with the arrival of new 'visible minorities'. Diversity has grown over the last fifty or sixty years with a general acceptance of the term 'super diversity' (Vertovec, 2007) to reflect the impact of globalisation, but our ideas seem to have remained firmly rooted in the era of multiculturalism. We have failed to distinguish multicultural societies and multicultural policies. Around the world, whether it is in Africa, America, Asia or Europe, we see societies becoming increasingly diverse in every sense - and they will undoubtedly become more so. But many multicultural policies have failed to respond to this completely different world in which the dynamics of diversity and personal and collective identities have fundamentally changed. The multicultural policies that we have used, particularly in the West, have failed to adapt and have become discredited as a result. It is salutary to reflect that multicultural policies are no longer advocated by virtually any politician and, as opinion polls and voting behaviours clearly indicate, nor are they supported by the public at large. This is true in the UK and in most other Western countries. But this is not simply a case of needing a new 'brand'. Rather, we need to regain support for our growing diversity, by developing interculturalism as a completely different concept which reflects the new realities of diversity.

I recognise that past multicultural policies were actually very successful in some ways; by promoting equality policies, developing positive action, in meeting diversity targets in workforces, using new housing strategies to tackle disadvantage, and in some other respects. It was right for the time and the fact that we managed to develop policies that avoided complete assimilation was a very great plus for the British model. The focus was, however, almost entirely on rights and positive action, together with anti-discrimination legislation (and the UK had some of the best), but we failed to ask how people could learn to live with 'difference' in a society in which that difference was constantly being re-defined.

\section{From Multiculturalism Past}

Academic multicultural texts over many decades have failed to recognise the modern realities in a number of respects. Firstly, difference no longer revolves around the interface between minority(ies) and the majority community. Of course this 'difference' is still a significant factor, but difference is now also defined internationally: by diasporas, by social media, by business and commercial forces and by a whole range of other transnational influences that simply were not accessible to the same degree, nor in the public sphere decades ago. And of course, difference is no longer defined by 'race'. Whilst this remains very salient for many people, multiculturalists have often completely ignored all other forms of diversity: gender, disability, sexual orientation, sectarian and faith differences, mental health and age and intergenerational conflict. It just saw difference as defined by the dominant race (and class) agenda, defined by the 1960s and '70s.

Multiculturalists did discuss one other important 'difference', that of nationality, but generally only in terms of how the majority in any country had to adapt to incoming minorities. And again this 
remains an important dialectic process, but there has been a failure to see the majority identity itself as developmental and constantly changing as a result of a range of influences. Multicultural theory has, for example, rarely considered the fundamental challenge posed to majority identities as a result of de-industrialisation and globalisation and other international processes, and has tended to reinforce the notion that it is under threat from internal pressures, particularly as a result of immigration. Throughout Europe, the rise of popular nationalist parties (PNPs) and the Far Right have also succeeded in presenting our national identities as being reshaped almost solely by immigration. This has ironically reinforced multiculturalist theory as it suggests to majority communities that it is possible to retain static 'essentialised' and 'groupist' (Meer and Modood, 2011) identities in the same way as that envisaged for minorities - as a protective shell to keep out external influences.

Indeed, for both the majority and minority communities multiculturalist concepts and polices had assumed that our identities were static and ascribed. Plurality and diversity were therefore seen as a threat, rather than something we could live with, or live in. For minorities in particular, these 'groupist' identities were reinforced in legislation in which Jews, Muslims, blacks, Asians, whites, Sikhs and many others, were homogenised into simple categories and then further 'essentialised' by inviting leaders, generally male, older leaders of communities to represent whole communities as though they were just one undifferentiated mass; and by providing funding for groups as though only people from that group could give services or care to people of the same group.

Any sense of the promotion of commonality, or good relations, was largely ignored, even though from the start of race relations legislation in the 1960s and further reinforced by legislation in 1976, the concept of promoting 'good relations' was embedded as a duty on public bodies (Cantle, 2008: 38-43). This was partly due to concerns about assimilation, but also because of the tendency for multiculturalists to rely upon a structural analysis, in which inter-community and inter-personal relations were regarded as an irrelevance. In fact, the duty was completely ignored for 50 years until community cohesion emerged out of the report into the 2001 race riots in northern towns in England (Cantle, 2001).

Community Cohesion began a different story about diversity. Whilst retaining a focus on tackling inequality and disadvantage, it suggested that it was important to find ways in which people could relate to each other across boundaries, rather than within boundaries. The Guidance produced by the Local Government Association in 2002 (LGA, 2002) made this very clear and also supported the development of a 'common sense of belonging' within its definition and proposed programme for local and voluntary agencies.

Yet, the concept of community cohesion was condemned by some academics as being some sort of political plot to create assimilation and undermine the struggle for equalities (Cantle, 2012: 35). This indicated a 'defensive' multiculturalism which may have been understandable in the context of the 1960s and '70s - the Enoch Powell 'Rivers of Blood' speech, trade unionist white dockers going on strike against immigration, widespread and overt discrimination - but it meant that the whole basis of multiculturalism was to close down debate. We failed to have 'dangerous conversations' precisely because they were dangerous: to give the oxygen of publicity to the Far Right was to invite community tensions to rise. But this 'defensiveness' did not change over the years and became part of a multicultural orthodoxy. It meant that people had few opportunities to come to terms with change: how did they ever begin to cope with the idea of difference if we were not prepared to debate it? Even when Nick Griffin, the Leader of the British National Party (BNP), appeared on BBC's Question Time in 2009 there was a furore and a strong reluctance to allow him on to prime time TV. But public attitudes had changed, even though multiculturalists had not recognised it and Mr Griffin was widely thought to have made a complete fool of himself, and is no longer the leader of the BNP. Multiculturalists could perhaps have justified their restrictions in the early post-war period, but have 
tended to argue for more, rather than less over the years and seem not to have noticed that far right parties are no longer able to attract support on the basis of crude biological racism (Goodwin, 2011: 8).

But this is still very much a current issue. One of the policies in front of the Home Secretary, Theresa May, is whether to allow extremists (even those who stop short of advocating violence or inciting hatred) to speak in Universities. Apparently, even university undergraduates cannot cope with the few wild rants of extremists and do not have the critical thinking skills to question and challenge them. If there is some truth in this, it suggests that society has failed to provide either a structured or experiential learning context for young people to cope with a modern multicultural environment.

If this is the case, it is perhaps partly because of the silo basis upon which multiculturalism has been constructed at an academic level. It has almost completely ignored the contribution of key disciplines, particularly anthropology and social psychology. Regrettably, in most of the established multicultural texts, there is barely a mention of any contribution from those disciplines. 'Contact theory' for example, is hardly ever mentioned and yet if we look at all the areas of difference gender, sectarian violence, people with disabilities or special needs - research has shown that contact can in fact change people's attitudes: it can disconfirm prejudices and undermine stereotypes. Allport's seminal work The Nature of Prejudice was published in 1954 (Allport, 1954), but it was never seen as part of the discourse on multiculturalism, since the emergence of community cohesion in 2001. From that intervention and largely through the work of Professor Miles Hewstone at Oxford University, we are beginning to see a renewed interest in contact theory, and not just in relation to race or ethnicity: there is now clear evidence that contact helps to reduce the apparent fear of 'others' and promote inter-group harmony (Hewstone et al, 2006) both directly and in a more contextual sense (Christ and Hewstone, 2014). Sociologists, in particular, have been subject of criticism for neglecting the value of 'cultural encounters' (Delanty, 2011: 642), confirming that no notion of permeable community boundaries, nor the beneficial impact of contact, interaction and exchange, were ever 'foundational' to multiculturalism, as suggested by Meer and Modood (2012: 182).

Multicultural theory also failed to 'join the dots'. It failed to see how prejudices could be altered in one sphere and that this could equally apply to another sphere. It also failed to understand how complex societies have become, and not just in a physical sense. The impact of the internet, the impact of social media, the impact of virtual connections, none of which have been been absorbed into our political understanding and certainly not into our multicultural thinking. National identity and national politics are now one of the key determinants of our idea of difference, but national identity has never played a role in multiculturalism, other than in the sense referred to earlier in that the majority has been expected to accommodate the minority. Multiculturalism has not reflected on the way that national boundaries are completely changing and being undermined from above, via international institutions and organisations (Held, 1989: 196; Agg, 2006: 2; Castells 2010: 419), and from below, through regional secessionist movements and the development of 'city states' (Barber, 2013).

However, notions of identity are also being profoundly changed as a result of the growth of the 'mixed race/ mixed faith/ mixed nationality'. Public policy has never recognised a mixed race community; they simply do not fit in to any of our purist, essentialised (and inherently racist), boxes. They are still seen as being 'other', but not part of any particular groupist category. Mixed relationships, of any kind, are still subject to community and social taboos, but are nevertheless the fastest growing of all ethnic categories across Europe. Similarly, LGBT relationships, perhaps now celebrated more than challenged, have added complexity to personal identity. However, the plea to oppose simple classification, as in 'You can't put me in a box' (Fanshawe and Sriskandarajah, 2010), 
is still largely disregarded by multicultural orthodoxy and policy. In fact, surveys of opinion particularly amongst young people across the world demonstrate that this plea is becoming increasingly commonplace and, in my view, is a hopeful rejection of the fixed ideas about identity which have pervaded multicultural policies. The latest IPSOS MORI poll for example, 'UK Becoming More Local, More Global' (IpsosMori, 2013) illustrates the extent of the change in the UK:

- $\quad$ Almost a quarter (24 per cent) say they feel a greater sense of connection to people in other countries around the world than they did ten years ago. For those aged 15-34 years, the figure is 31 per cent.

- $\quad$ More than four in ten (44 per cent) say that their leisure activities are important to their identity, with a similar proportion saying their values or outlook matter (38 per cent) and slightly fewer saying their personal views and opinions are important (34 per cent).

- Traditional factors of age (22 per cent), nationality (20 per cent), gender (13 per cent), class (7 per cent) and ethnicity ( 6 per cent) were viewed as less important to people's identity.

- $\quad$ Only 20 per cent said their nationality was among the top three or four things they would tell a stranger was important about them. Only 10 per cent said religion, while 7 per cent picked social class.

Despite having little by way of encouragement, a surprising number of people are thinking of themselves in more complex terms and it is particularly striking that none of the new key aspects of identity are those that are generally ascribed at birth.

Similarly, a 2008 world public opinion survey (WOP, 2008) in twenty-one nations around the world found that nearly 30 per cent of people now saw themselves as a 'citizen of the world' (10\%) as much, or more than, as a citizen of their nation (20\%). Further, the more people know people from different regions of the world, the more they see themselves as a global citizen-rising to 47 per cent among those who know people from five or more regions. As might be expected, the larger number of respondents from around the world (66 per cent) said that they think of themselves primarily as citizens of their country, but this varied considerably by country. In the poll, the nations with the highest numbers saying they primarily think of themselves as 'citizens of the world' were Italy (21 per cent) and Germany (19 per cent). Very substantial numbers said they see themselves as either a citizen of the world or as equally a citizen of the world and their country. These include France (51 per cent), China (50 per cent), Italy (48 per cent), India (46 per cent) and Mexico (44\%). The lowest levels are found in Azerbaijan (9 per cent), Kenya (12 per cent), Jordan (15 per cent) and South Korea (16 per cent). Younger people tend to be even more globally oriented than older people.

So, we are failing to represent this generation and the many people across the world who resist being put into the predetermined identity 'boxes', and recognise that they now define themselves in relation to region, local place, brands, friendship and social media and in many other ways. And the problem of national politics is closely linked to ideas about national identity. Across Europe, we have witnessed a fall in trust and support for mainstream politics. Far right and popular nationalist parties (PNPs) are developing because national identities are seen to be under threat, with, for example, the French Front National regularly garnering $25 \%$ of the national vote on what is presented as the contradiction between nationalism and globalisation (Cantle, 2012: 83; 85; 170).

Whilst multicultural policies have almost completely neglected this area of identity and change, governments have also failed to respond in a positive way. There has been a reluctance to allow dual nationality and a tendency to limit voting rights, for example by restricting foreign nationals' rights in local elections. Rather, there has been rather crude campaigns to try reassert a simple and bounded national identity. Most European countries have now introduced citizenship tests, citizenship 
ceremonies and some form of citizenship education. In the UK this recently extended to changing the English school curriculum to exclude To Kill a Mockingbird from the reading list because it is an American, not a home grown, English text!

\section{To Future Interculturalism}

We fail to provide an intercultural education, in which people have the opportunity to come to terms with the way in which the world is changing and insist on an identity classification system based on exclusivity. As an example of this, I often cite a young woman who has described her many identities - as 'a Glaswegian, Pakistani teenager of Muslim descent who supports Glasgow Rangers in a Catholic school'. This is an example of plurality now commonplace amongst younger people who have many choices to make and these will vary over time and in different situations. I have been surprised to find that other speakers representing a multiculturalist view are, in some cases, challenged by this and continue to suggest that identities are ascribed, stuck and static, or that such identities are in competition with each other, rather than accepting plurality.

The mentioned young woman may well actually have a different identity at home compared to that at school; she might have a different identity next week and able to see it as developmental, and constantly changing. Part of her identity happens to be her 'Muslimness' and that is the box that public policy will currently use as a default. Public policy has not even begun to learn how to cope with this multiplicity and this is simply not addressed within multicultural theory - we continue to reinforce bounded identities through support to the community leaders (who often seek to impose all sorts of impossible choices on the members of their own community, for example in respect of marrying out, sexuality and apostasy) and with which public policies connive. And we create a tick box classification which homogenises communities under a single aspect of their identities.

Academic multicultural texts did begin to refer to hybrid identities from the 1990s, but they rather missed the point that simply extending the number of categories only results in what Sen (2006: 156) called 'plural monoculturalism', a simple retention, by extension, of the notion of bounded and settled identities. Sen elaborates on this and refers to the 'miniaturisation' of people and their identities (Sen, 2006: 175), pointing out that the 'illusion of a unique identity' is part of the process in which conflict and violence are sustained today: 'the world is increasingly divided between religions (or 'cultures' or 'civilizations'), which ignore the relevance of other ways in which people see themselves through class, gender, profession, language, literature, science, music, morals or politics' (Sen, 2006: 175).

The boundaries of identity have been reinforced by many different forms of segregation. In so far as this is discussed in multicultural texts, it is limited to residential patterns and simply attributed to economic position. It is of course the case that, in this form, it is linked to socio-economic factors, but it is in no way confined to race and ethnicity and segregation is found in many other dimensions - schools, workplaces, social care and health, sporting and leisure pursuits and cultural areas - and is not limited to race and ethnicity. Segregation, in a number of domains, results in what I described in my 2001 report (Cantle, 2001) as 'parallel lives', in which people have no contact with 'others' helping to create a wider fear and intolerance of 'otherness'. But the more general problem lies in how we break down barriers at these levels to facilitate contact and provide opportunities for people to recognise commonalities. Creating shared spaces, where people can encounter people who are different from themselves does change attitudes: it can disconfirm stereotypes, undermine prejudice and actually ensure that people are much more comfortable with diversity. This has never been recognised by multiculturalists who generally ignored evidence from other disciplines and 'contact theory' and other models of interpersonal and inter-communal dialogue has been almost completely absent from the debate about multiculturalism and difference, whereas it is central to interculturalism. 
Interculturalism also has to have at its heart the tackling of inequalities and disadvantage, but it is about doing something more than that, it is about developing a wider community narrative, projecting diversity as a positive, and trying to change attitudes as well as behaviours. In so doing, interculturalism has had to consider the attitude of the majority communities, and attempting to understand their anxieties. Majority communities are also facing change; de-industrialisation, the growth of corporate power, the growth of international financial institutions, the mobility of labour and capital. The many influences on identity form part of an intercultural programme.

The role of schools and colleges is especially important. It is essential, in my view, that all schools provide a religious literacy, including discussion of atheism and secularism, and that they ensure contact with, and knowledge of, communities who are different from themselves. This will enable them to cope with a globalised world in which 'difference' is now an everyday reality. In the UK, schools have unfortunately been asked to pay less attention to their 2007 'duty to promote community cohesion' and are increasingly balkanised by policies which encourage separation by faith, ethnicity and class. Schools should nevertheless embrace this and the wider programmes which include parents and other community members: they could be the champions of change. Intergroup contact needs to be made much more pervasive on an experiential learning basis, in which people can experience diversity in a non-threatening and enjoyable way. There are now many examples of such programmes (Cantle, 2012: 194-212) and implementation of intercultural policies (Cantle, 2015) and these have been fostered on a pan-European basis by the Council of Europe's programme for 'Intercultural Cities'. Leadership and a positive vision for 'living with diversity' is also crucial (Cantle, 2012: 176-188).

Multiculturalists have also tended to shy away from criticism of some cultural practices and to represent them as an attack on minorities, a form of covert racism. As part of this process almost any debate has been closed down to avoid even the possibility of such attacks, as in the Nick Griffin example discussed earlier. This 'cultural relativism' debate has had the effect of removing the opportunity for real challenge and learning and led to accusations of an enforced 'political correctness'. The current concern is about free speech in relation to faith, with a continuing 'privileging' of faiths by virtue of legislation, cultural taboos and privileged positions (e.g., faith representatives given access to politicians and reserved seats in the UK House of Lords).

As the tragic Charlie Hebdo affair illustrated, this debate is full of difficulty, but faiths surely need to accept that if they have a protected position within the public sphere, then the contestation of faith also needs to be protected in the public sphere. We also need to distinguish the concepts of a 'secular society' from 'secular governance' (Cantle, 2012: 188-194). I agree with those who argue that we should not tolerate the intolerable and that we should contest what we believe to be unacceptable practices - for example, I see no reason to respect the views of the institution of Scientology. But recently, those contesting the role and nature of faith have been accused of being 'aggressive secularists' by UK ministers. Secularism is a basic British value which people have died protecting and yet its advocacy is now condemned, illustrating the confused and mixed messages over 'free speech'. The point is that debate and challenge give us the confidence and competence to live with, or in, diversity.

We also need the confidence as individuals to move beyond our personal identity. It is worth remembering the words of Sheikh Ibrahim Mogra, an imam in Leicester when he was being pressed by a TV interviewer to give his views as a Muslim, he said 'Yes, I am a Muslim but I'm a human being first'. What multiculturalists have to learn is that plural identities are not in conflict with one another; heritage complements other forms and does not define us for all time and each becomes another facet of our understanding and personal story. 


\section{References}

Allport G.W. (1954) The Nature of Prejudice. Cambridge: Addison Wesley.

Agg C. (2006) Trends in Government Support for Non-Governmental Organizations. Geneva: UN Research Institute for Social Development.

Barber B (2013) If Mayors Ruled the World. New Haven: Yale University Press.

Cantle T (2001) Report of the Independent Community Cohesion Review Team (The 'Cantle Report') London: Home Office.

Cantle T (2008) Community Cohesion. Basingstoke: Palgrave.

Cantle T (2012) Interculturalism. Basingstoke: Palgrave.

Cantle T (2015) Implementing Intercultural Policies. In: Zapata-Barrero R. (ed) Interculturalism in Cities. Stockport: Elgar.

Castells M (2010) The Power of Identity. Chichester: Wiley-Blackwell.

Christ O, Schmid K, Lolliot S, Swart H, Stolle D, Tausch N, Al Ramiah A, Wagner U, Vertovec S, and Hewstone M (2014) Contextual effect of positive intergroup contact on outgroup prejudice. Proceedings of the National Academy of Sciences, 111(11): 3996-4000.

Delanty G (2011) Cultural diversity, democracy and the prospects of cosmopolitanism. The British Journal of Sociology, 62(4): 633-656.

Fanshawe S and Sriskandarajah D (2010) You Can't Put me in a Box. London: Institute for Public Policy Research.

Goodwin M (2011) New British Fascism. London: Routledge

Held D (1989) The decline of the nation state. In: Hall S and Jacques M (eds.), New Times. London: Lawrence \& Wishart, pp. 191 -204.

Hewstone M, Paolini S, Cairns E, Voci A and Harwood J. (2006) Intergroup Contact and the Promotion of Intergroup Harmony. In: Brown R.J. and Capozza D. (eds) Social Identities. Hove: Psychology Press, pp 209-238.

IpsosMORI, (2013) UK becoming 'more local and global' http://www.ipsosmori.com/researchpublications/researcharchive/3365/UK-becoming-more-local-andglobal.aspx

Local Government Association et al (LGA) (2002). Guidance on Community Cohesion. London: LGA.

Meer N and Modood T (2011) How does inter- culturalism contrast with multiculturalism? Journal of Intercultural Studies, 33(2): 175-196.

Meer N and Modood T (2012) Interculturalism, multiculturalism or both? Political Insight 3(1): 30-33.

Sen A (2006) Identity and Violence. New York: Norton.

Vertovec S (2007). Super-diversity and its implications. Ethnic and racial studies, 30(6): 1024-1054. 
World Opinion Poll, 2008, http://worldpublicopinion.org/pipa/articles/views on countriesregions bt/608.php?lb=brg| m\&pnt=608\&nid=\&id

\section{What is Multiculturalism and What Can it Learn from Interculturalism?}

\section{Tariq Modood}

Multiculturalism has a variety of meanings; it is useful to begin by identifying some of them in terms of three different levels.' Multiculturalism is a body of political ideas or theory. There is also the level of multiculturalism as policy and state action, whether at a national or local level, or sometimes civil society initiatives. Thirdly, there is the level of a climate of opinion. It is quite clear that the present climate of opinion in western Europe and so many other places is rather anti-multiculturalism. I will not here be addressing the latter. Rather, I want to explain what I think multiculturalism is at the level of theory and policy, because as I understand it, Professor Cantle and others believe its failures at those two levels have led to its unpopularity at the third level. I will conclude by all too briefly indicating what multiculturalists can learn from interculturalist authors and approaches

The core concept of multiculturalism is citizenship, a focus it shares with other '-isms' such as liberalism and perhaps also interculturalism. By citizenship here, I don't mean simply a legal framework, the possession of rights and obligations, a passport, the right to vote and so on. I mean a form of membership, a relationship with each other which has to be expressed within an ethical, principled framework. The law, legal entitlements and legal protections are part of that. They are, if you like, the skeleton, and citizenship is the whole body, the flesh on the skeleton. This ethical framework is informed by key ideas like liberty, equality, fraternity or unity and democracy. In liberal theories, citizenship is principally understood in terms of the relationship between the individual and the state and so citizenship is primarily thought as rights against the state. But there are more republican conceptions of citizenship, as well as my understanding of multicultural citizenship, in which a vertical relation between an individual and the state is complemented by a horizontal one between citizens. Citizenship, then, given the ethical framework I am talking about. It is the ethics of civility, the ethics of how we relate to each other as citizens and not just rights against the state.

\section{Two Concepts of Equality}

Citizenship, then, is not distinctive to multiculturalism. I take the classic idea of equal citizenship in liberalism to be the right to assimilate to the majority or dominant culture in the public sphere, with toleration of difference in the private sphere. Toleration, however, is a limited good because it is dependent on the goodwill of the person who is doing the tolerating, presumably the more powerful section of society, such as the majority, which can withdraw its toleration if it so chooses. More fundamentally, I would say that this liberal concept of equality is a very important because it embodies our understanding of non-discrimination, that citizens should not experience discrimination on the basis of dimensions like race, ethnicity, gender, disability and so on. Equality or equal membership as having the same rights and not being discriminated against is a feature of all concepts of equal citizenship and so also of multiculturalism. It is the idea of equality that Martin Luther King was arguing for in terms of the African- American struggle for civil rights. There is, however, a flaw in this liberal concept; it creates two classes of citizenship whether it means to or not. It creates those who are the full, normal, unproblematic citizens and the others about whom there is some form of problem; a problem which is resolved by them becoming like the first class, assimilating to that class. Multiculturalism identifies this inequality in the basic concept of equality, and it responds to that equality deficit by arguing that we need a supplementary concept of equality 
in order to properly have equal citizenship in the context of diversity. This secondary concept of equality is not to replace the first, but to supplement it. It may be understood as the right to have one's difference recognised and supported in both the public and private spheres. So no group, no minority for instance, can be told we will tolerate your difference; but please do not bring it into the public space, do it in your own space somewhere; do it at the weekend, do it in your community, but do not make demands on mainstream public institutions. The multicultural response is that this is not equality. Equality is that minorities can make a comparable demand to share the public space as the majority does. So whilst classical liberalism is about the first concept of equality, multiculturalism is about two concepts of equality, because it is supplemented by the second. It follows then that multicultural equality is more than individual rights and more than what we might call colour-blind equality, equality as sameness. Let me emphasise - because so many people take multiculturalism to be saying the opposite - nothing I have said is about separatism or primacy of ethnic identity. It is certainly about the inclusion of ethnic identity, but it is not about which identity is primary or secondary. Rather, we should understand these two concepts of equality in terms of what is unreasonable or unjust in the treatment of minorities.

\section{Four 'Rights' of Minorities}

From these dual concepts of equality taken together, we can derive what we might call four 'rights' of minorities (but not reducible to legal rights). Firstly, protection from racism, including cultural racism and Islamophobia - not protection from majority culture; protection from certain kinds of hostility that may be present in the majority culture, not protection from majority culture per se. I think all liberals and egalitarians agree on this; this is in effect the first concept of equality. Multiculturalists expand this negative protection to include 'recognition', which is clearly an aspect of the additional concept of equality stated above, the need to allow and support difference in the public and private spheres. That's clearly going beyond anti-discrimination. It is including minority ethnic identities, religious identities, identities based on racial solidarity like Black identity and so on as bases of inclusion and of shaping the public space. They are publicly recognised as a part of, say, being British and not merely not-excluded by national institutions.

The second derivation from the two concepts of equality is that there should be no insistence on assimilation, but nor should there be any hindrance against uncoercive social processes of assimilation or self-chosen assimilation. Which I hope underlines that multiculturalism is not against assimilation, only against coercive or pressured assimilation, not against self-chosen assimilation. Another way of expressing the same point is to say there can be different modes of integration of which assimilation might be one, multiculturalism can be another, possibly inter-culturalism could be another, and different modes of integration should be equally welcomed. Assimilation should be given no special priority over the recognition of difference. It is true that some people of immigration origin say, 'look, forget my background I just want to be like everybody else'. There is nothing wrong with that, multiculturalists are not tut-tutting about that. No one should be pressured to efface the identities that matter to them; but, if they do not matter to them, if they are happy for them to fade away, then that is good too.

The third item is there should be multicultural accommodation of minorities within shared public institutions. This again is really spelling out the implication of the second concept of equality and what I have already said about recognition of group identities and their cultural needs. It could be, say, having access to halal meals in public institutions like schools and hospitals; it might be the right to wear certain kinds of dress within public places. In France they have banned Muslim headscarves in schools and have banned face veils in all public places. Those are good examples of the opposite of multiculturalism; multiculturalism is about accommodation and inclusion, not about banning and excluding. 
My last 'right of minorities' is that they should be able to make claims on national and civic identity. That, after all, is what the majority does, it creates the public space to reflect their own identity, their own evolving, historic identity. Minorities should be able to do that as well, and to do that in their own ways; this joint remaking of national identity, then, is part of multicultural citizenship. Multicultural citizenship involves the remaking of national identity, not its dissolution or denial of it. At any time, but especially given the various legacies of racism and colonialism, such as those of European countries, the status quo can be quite exclusionary. Hence the project of remaking national identity should be welcomed and encouraged by the majority. This should be done in ways to enhance shared and overlapping senses of belonging and to reduce alienation and fragmentation.

That then, within the space available, is how I understand multiculturalism in terms of theory. I turn now, equally briefly, to say a little about the second meaning of multiculturalism, namely the level of policies. As the debate between Ted Cantle and I arises specifically in relation to (what has gone wrong in) Britain, I will focus on this country.

\section{British Multiculturalism}

The story of British multiculturalism begins in the 1960s with the recognition of the fact of widespread racial discrimination and steps taken to start outlawing it in the 1965, 1968 and 1976 Race Relations Acts. That of course is not distinctive to multiculturalism, it is part of liberal equality and as such is mainly an appeal to the first concept of equality. However, as the dynamic unfolds we begin to see the emergence in practice of the second concept of equality, of equality across difference, especially in the 1980s. A significant moment is the House of Lords judgement in the case of Mandala versus Dowell Lee, in which the Lords decided that prohibiting Sikh males from wearing turbans in schools (and by extension in other public spaces, like workplaces) was discriminatory within the meaning of the Race Relations Act (1976). What that 1982 decision did, though this, was not immediately recognised and took a few years for it to work itself out, was it put Britain on a trajectory away from racial dualism to ethnic pluralism. From the 1960 s to about the end of the 1980s, most policymakers, politicians, opinion formers and so on, thought the issue of racial equality could be understood in terms of black and white (Modood, 1988; Modood 1994). The majority population, the native population is white; people who have entered the country are black and are being treated discriminatorily. The 1982 decision showed that this was not an adequate understanding of British society as it was developing. After all, there is nothing about wearing a turban that is about being black or white. White Sikhs have a duty to wear a turban, just as brown Sikhs or black Sikhs do. So it is not about being black or white, and thus the House of Lords took what originated as a colour-based concept and extended it to include ethno-religiosity. Later in the 1980s, some Asians started asking that British institutions, including the Commission for Racial Equality (CRE), where I worked at the time, recognise us as Asians, querying why the CRE designated us as 'black' when Asians do not think of themselves as black. Given what I have said about the importance of recognition to multicultural equality and the harm of misrecognition, of denying people the identities that they assert, it was difficult for the original racial dualist model of equality to resist these protests, which not immediately but soon prevailed (Modood, 1988; Modood 1994). This Asian identity assertion against the bureaucratic and political activist identity of blackness was an important step in the gradual enfolding of British multiculturalism, especially in the transition from a racial to a multi-ethnic equality perspective.

The next step I now turn to, the Salman Rushdie Affair, was much more dramatic and conflictual, but was absolutely pivotal to British multiculturalism. I will go so far as to say, British multiculturalism properly takes off with the Rushdie affair. It is, I believe, the single most important event in the story of British multiculturalism. So what was the multiculturalist response over the battle of the novel, The Satanic Verses? Let me mention four key things. Firstly, multiculturalists said stop condemning Muslims in a rhetoric of absolutist freedom (the same rhetoric that we have recently heard so loudly 
in France and elsewhere after the killings at the Charlie Hebdo office, and the other killings associated with it). Stop condemning, listen. Britain needs to have a dialogue with Muslims about what is the problem. Why are they angry, why do they feel hurt? Don't condemn, don't resort to an absolutist, unrealistic conception of freedom of speech, listen. That was the first thing multiculturalists said (Parekh, 1989; CRE, 1990a). Secondly, we said, actually what we need to do is to extend the concept of incitement to racial discrimination and hatred, which was already in British law, to cover religious discrimination and hatred (CRE, 1990b; Modood, 1993). Because multiculturalism is about extending what I called racial dualism to ethnic pluralism, which we saw embodied in the House of Lords decision of 1982 about the Sikhs' turban, the Rushdie affair took it further because it went beyond ethnicity to religion more squarely. Of course Sikhs are a religious group as well, but they, together with one other religious group, the Jews, enjoyed protection under racial equality legislation in the way that Muslims did not. The need to not just protect Muslims from discrimination and incitement to hatred, but to positively recognise them and institutionally accommodate them in a multiculturalist way was the third lesson of the Rushdie Affair. And if we broaden that out from Muslims to acknowledge religion more generally, that is to say, the importance of religion to self-identity and public life, in the same way that we recognise the importance of ethnic identity (or gender or sexual orientation identity), we have the fourth lesson of the Affair for multiculturalism.

\section{New Labour}

Moving on chronologically, we come to New Labour. I would say that New Labour's first term (19972001) is probably the most multiculturalist British administration; certainly considering some of its policy initiatives gives a good idea of what I mean by multiculturalism at a policy level. I do not have the space to discuss specific policies but let me simply list the initiatives that I have in mind:

\section{- $\quad$ Abolition of Primary Purpose rule in relation to immigration \\ - $\quad$ Faith Schools: the funding of Muslim and other faith schools (on the same basis as Christian and Jewish schools).}

- $\quad$ The bringing in of Muslims (mainly the Muslim Council of Britain at the national level) into governance on the same basis as other identity and interest groups.

The MacPherson Inquiry and a high profile discussion of institutional racism and requiring an appropriate programme of action from the London Metropolitan Police and other state bodies.

- $\quad$ Race Relations (Amendment) Act 2000, strengthening the previous equality legislation, especially in relation to the duty of public bodies to actively promote racial equality.

The selective targeting of disadvantaged groups such as Bangladeshis, Pakistanis and African-Caribbeans in relation to education and employment policies, while recognising that other minorities such as the Chinese and Indians were not disadvantaged relative to whites in these policy areas; that the relevant divide was not white/non-white.

The instituting of Holocaust Memorial Day.

The introduction of a Religion question in 2001 Census.

Of course multiculturalist policies were enacted beyond 2001 too (e.g., introduction of anti-religious discrimination offences in 2003 and 2006 and upgrading them to the same level as racial and sexual equality in 2010), but I hope it can be gleaned why I think these policies are illustrative of those multiculturalist ideas as presented above and why - with perhaps only slight exaggeration - this period could be described as the heyday of British multiculturalism. I emphasise this point because 
Ted Cantle has argued that multiculturalism was in the 1960s-1970s (Cantle 201X) and others have argued that it was in the 1980s (Goodhart, 2013). My disagreement with these authors is then not only about what multiculturalism is but which period was it most alive in. Similarly, if someone says, as Prime Minister Cameron has said, that he is against state multiculturalism (Cameron, 2011), this is what I take him or her to be against. Conversely, if someone says they are in favour of state multiculturalism, as I say I am, this is what I take them to be broadly in favour of, at least in Britain.

\section{Multicultural Britishness}

The final point I want to make about Britain relates to my contention that that remaking of national identity was central to the idea of multiculturalism. Consider what British prime ministers had been saying about British national identity. In the 1970s and 1980s, Mrs Thatcher wanted 'to keep fundamental British characteristics' (Thatcher 1999) and in the 1990s John Major hoped that 'fifty years from now Britain will survive.... un-amendable in all of its essentials' (Major 1993). New Labour had a very different view of Britain: for them it was not so much about a thousand years of history, as it was for John Major, but it was a country on the move, 'a young country', as Tony Blair described it. In such rhetoric and that of 'cool Britannia', the New Labour was signalling a brand that foregrounded changing lifestyles, urban multiculture, the creative arts and youth culture and the ethnic minority dimension within them. Jack Straw, the Home Secretary (1997-2001), had spoken about Britishness having become more inclusive and multiethnic, and Robin Cook, a senior Cabinet figure, in a highly publicised speech had referred to chicken tikka masala as the favourite national dish. The Commission on Multi-Ethnic Britain (CMEB), which published a high profile national report in 2000," was aware of how the New Labour was recognising the growing multiculturalising of the national identity. The Commission, however, was not content for senior politicians to merely acknowledge this, as we thought this led to the complacent view that the process could be left to itself, that no action or political leadership was necessary. We wanted to challenge that complacency and passivity, what we referred to as 'multicultural drift'. The CMEB report was widely denounced as anti-British and anti-patriotic in 2000, including by Jack Straw (Richardson, 2000). Nevertheless, soon afterwards, Cabinet members started expressing exactly the view that had been lambasted. In 2001, John Denham argued that Britishness, as it existed, was insufficient, and hence 'positive action must be taken to build a shared vision and identity...' (Denham 2001), and in 2007 Jack Straw himself said that it was necessary 'to develop an inclusive British story which reflects the past, takes a hard look at where we are now and creates a potent vision...to make sense of our shared future...' (Straw 2007). Note the active verbs: 'build', 'develop', 'creates' - exactly the view that had motivated the

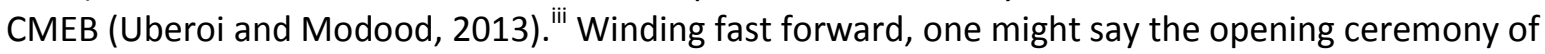
the Olympic Games in London in July 2012 was an excellent expression of a multicultural Britishness that the New Labour tried to articulate without ever quite succeeding, and its positive reception in the British media - including the same papers that had lambasted the CMEB - shows how far we have advanced (Katwala 2012).

\section{Welcoming the Contribution of Interculturalisms}

I believe this is a robust defence of British multiculturalism (within the space available). However, it is not my view that multiculturalism has always been implemented well or that it cannot theoretically be improved. Specifically, I think there are at least four points that interculturalists have expressed better than many multiculturalists. Namely:

- The importance of inter-group contact and cohesion, not merely multicultural co-existence at a local level and through co-operation and everyday encounters (Cantle Report, 2001) ) $^{\text {iv }}$

- The importance of a diversity perspective attending to the normative claims of the majority and historic nationhood as argued by Quebecan intellectuals (Bouchard, 2011 - which I engage with in Modood, 2013) 
- The importance of valuing national citizenship and of displaying this symbolically and discursively as for example in Citizenship Ceremonies (first highlighted by the CMEB, 2000: 55, and substantially developed within a wider appreciation of citizenship and citizenship education, Crick, 2003)

- The recognition of the multiplication of the 'multi' and the fluidity, complexity and internal diversity of the identities at the centre of multiculturalism through concepts such as 'new ethnicities' (Hall, 1988) and 'superdiversity' (Vertovec, 2007); and beyond this the challenge of a diversification in the nature of migration, including people who have no historical connection to the country of settlement and those who may prefer mobility to settlement and national citizenship.

I do not have the space to do more than simply list these but they have all been beneficial to the development of multiculturalism by posing critical challenges or by developing further the work of multiculturalists. The last point, namely the recognition of multiple identities is one that multiculturalists have long recognised but have had to balance it against the fact that for some people certain identities are paramount, they are absolutely central (Modood, 1998). There are a lot of black people who will say whatever I am - rich, poor, a chartered accountant or whatever - being black is absolutely central to who I am in British society. Similarly, a lot of women will say their gender identity is absolutely central. Similarly, studies show that an overwhelming number of Muslims will say they are a Muslim within the first, second or third identity description (Modood, 2007/2013: pages xxx and xxx). They will of course also offer other descriptions, like they are British but being a Muslim isn't part of being a multiple identity in the sense that Cantle means it, something limited to some contexts. For some minorities, especially those who are beleaguered, who are being harassed all the time, having fingers pointed at them for being backward, alien, for not fitting in, for being terrorist and so on, their minority identities stick to them. To get beyond the stigmatisation and marginalisation we need the public recognition that multiculturalism offers as the second concept of equality. Hence, we cannot ask all minorities to wear their identities lightly, flexibly and contextually - to do so becomes a kind of postmodern assimilationism.

That then is an example of how multiculturalists can learn from interculturalist emphases without accepting them as initially offered or giving up on multiculturalism. It is in this way that contributions such as those listed above that I think various versions of 'interculturalisms' have supplemented and developed the multiculturalism that I have set out. It would however been wrong to think of interculturalism, either theoretically or in policy terms, as a replacement of or successor to multiculturalism; it fits in within, even while disputing parts of, the same theoretical and policy frame. In this respect, interculturalisms, both the Quebecan and European versions, are not really independent political conceptions and are best understood as critical friends, not alternatives to multiculturalism, or, stronger still, as partial versions of multiculturalism (Meer and Modood, 2013; Meer, Modood and Zapata-Barrero, forthcoming, 2015/16).

\section{References}

Bouchard G (2011) What is interculturalism? McGill law Journal, 56(2): 435-468.

Cameron, D. (2011), PM's Speech at Munich Security Conference, 5 February, http://www.number10.gov.uk/news/speeches-and-transcripts/2011/02/pms-speech-at-munichsecurityconference-60293

Cantle T (2001) The Cantle Report, London: Home Office.

Cantle, T. (201x) 
Commission for Racial Equality (1990a) Law, Blasphemy and the Multi-Faith Society, London.

Commission for Racial Equality (1990b), London.

Commission on Multi-Ethnic Britain (CMEB) (2000) The Future of Multi-Ethnic Britain. London: Continum.

Crick B (2003) Advisory Group on Life in the UK, Interim Report. London: HMSO.

Denham J (2001) Building Cohesive Communities: A Report of the Ministerial Group on Public Order and Community Cohesion. London: Home Office.

Goodhart D (2013) The British Dream. London: Atlantic Books

Hall S (1988) New Ethnicities. In: K. Mercer (ed.) Black Film, British Cinema. London: Institute of Contemporary Arts, BFI/ICA Documents 7.

Katwala S (2012) An Island Story: Boyle's Olympic Opening was Irresistibly British. Open Democracy, 31 July, http://www.opendemocracy.net/ourkingdom/sunder-katwala/island-story-boyles-olympicopening-was-irresistibly-british

Major J (1993) Speech to the Conservative Group for Europe, 22 April, http://www.johnmajor.co.uk/page1086.html (last accessed 20 December 2012).

Meer N and Modood T (2012) How Does Interculturalism Contrast with Multiculturalism?' Journal of Intercultural Studies, 33(2): 175-96.

Meer N, Modood T and Zapata-Barrero R (forthcoming, 2015/16) Interculturalism and Multiculturalism. Edinburgh: Edinburgh University Press.

Modood T (1988) “Black”, Racial Equality and Asian Identity. New Community, 14(3): 397-404.

Modood T (1993) Muslims, Incitement to Hatred and the Law. In: Horton J (ed.) Liberalism, Multiculturalism and Toleration. London: Macmillan.

Modood T (1994) Political Blackness and British Asians. Sociology 28(4): 859-876.

Modood T (1998) Anti-Essentialism, Multiculturalism and the 'Recognition' of Religious Groups. Journal of Political Philosophy, 6: 378-399.

Modood T (2007/2013). Multiculturalism. First Edition (2007), Second Edition (2013). Cambridge: Polity Books.

Modood T (2014) Multiculturalism, Interculturalisms and the Majority. Journal of Moral Education, 43(3): 302-315.

Parekh B (1989) Between Holy Text and Moral Void. New Statesman and Society, 24 March, London.

Richardson R (2000) 'Children Will Be Told Lies': Distortions, Untruths and Abuse in the Media Coverage. The Runnymede Bulletin, Winter, pp. 12-17.

Straw J (2007) Cyril Foster Lecture, Oxford University. 25 January.

Thatcher M (1999) World in Action Interview. In: Thatcher M (ed.) Complete Public Statements: 1945-90. Oxford: Oxford University Press. 
Uberoi V and Modood T (2013) Inclusive Britishness: A Multiculturalist Advance. Political Studies, 61(1): 23-41.

Vertovec S (2007). Super-diversity and its implications. Ethnic and racial studies, 30(6), 1024-1054.

Commentary: 'Interculturalism vs Multiculturalism - How can we live together in diversity'

Raffaele lacovino

It must be noted at the outset that the matter of identifying qualitative distinctions between the models of multiculturalism and interculturalism has been the subject of much contestation in the Canada/Quebec imbroglio for some time. Both models reflect a commitment to a liberal-pluralist normative framework - that is, a public sphere that acknowledges certain forms of collective identity as constitutive of citizenship; both reject a strictly civic legal framework for delineating the terms of belonging, where culture is relegated to one's private concerns; and both abandon explicitly assimilationist approaches as morally excessive, rejecting the notion that a majority culture ought to serve as a structuring political subject. The debate here seems to reflect similar lines of consensus the ethical individualism inherent in certain iterations of liberal thought is taken as unsuitable for diverse societies.

Yet, I want to argue that this debate also reveals a particularly salient aspect of conceptualizing models of integration - the sociopolitical context within which such models are elaborated and applied. The main source of contention between Tariq Modood and Ted Cantle seems to revolve around the relevant collective identities to which we apply pluralist policies. Briefly, Cantle is concerned that supplementing liberal equality through the recognition of ascriptive characteristics fails to grasp the complexity of contemporary identities that are formed, elaborated, expressed and revised in a multiplicity of ways that cannot be captured through pre-determined categories such as race, ethnicity or culture: “(...) we failed to ask how people could learn to live with 'difference' in a society in which that difference was constantly being redefined." As such, multiculturalism is seen as an approach for a different era, where anti-discrimination policies, affirmative measures premised on rights and equality promotion were geared towards ensuring that the terms of belonging defined by citizenship could move beyond cultural assimilation as the dominant paradigm. For Cantle, our era is characterized by a sociological diversity nourished by a variety of influences, and initiatives based strictly on the recognition of ethnocultural groups tend only to reinforce the static and essentialized nature of a 'groupist' imaginary. Interculturalism thus challenges multiculturalism to emphasize interaction and exchange between a multiplicity of complex collective identities, including the cultural majority, in order for a new referential public space to be forged that will more authentically displace a national integration project beyond a culturalist paradigm.

For Modood, this is also a welcome development. He explicitly states that multiculturalism within a liberal framework does not seek to force individuals into certain 'boxes', and people are free to determine the ends of their lives autonomously. Multiculturalism is only taken as a corrective of sorts, redressing the tendency for liberal societies to serve the ends of a majority culture at the expense of others. Otherwise stated, national identity as the substantive cornerstone of citizenship has traditionally been intertwined with the terms of reference defined by majority cultures, and multiculturalism as an idea acknowledges that the national narrative can and ought to be inclusive of different cultural influences. For Modood, moving to the public recognition of undifferentiated collective identities as the basis for social cohesion, without a nuanced appreciation of the sorts of robust cultural identities that are constitutive of citizenship, suffers from a potential slide towards "postmodern assimilation" - where initiatives based on the promotion of pluralism are stripped of their capacity to address specific instances of oppression and marginalization. In the scenario 
promoted by Cantle, cultural pluralism as a normative paradigm starts to look a lot like liberal thought that seeks to relegate robust collective identities to the private sphere - as mere expressions of individual preferences or life choices.

Now in the Canadian context a similar debate is taking place, but the models themselves are meant to serve different ends. Interculturalism in Quebec, as an alternative paradigm that contests Canadian multiculturalism in structuring the terms of belonging, is meant precisely to ensure the continuity of a project for national integration in the face of a model for cultural pluralism that fails to recognize the structuring capacity of majority cultures in organizing public institutions. The fine balancing act between reconciling the norms of pluralism, on the one hand, and the constant need for national affirmation on the other, has resulted in a model - interculturalism - which unambiguously seeks to reclaim a culturalist understanding of the political sociology of citizenship as it relates to the nation form. This renders the Quebec variant very distinct from a conception of interculturalism that is premised on an undifferentiated identity landscape. Quebec in a sense uses interculturalism to arrive at a conception of the nation in which cultural identity plays a lead referential role.

Indeed, a recent piece by Charles Taylor (2012) identifies the existence of a "reigning historical identity" as the very reason for the elaboration of a distinct model meant to serve as an alternative to multiculturalism. In opting for a model that recognizes ethnocultural communities as equally constitutive, Canadian multiculturalism is interpreted by Quebec nationalists as an explicit attempt by the wider associative community to deny Quebec's status as a host society and a founding nation. All collective claims premised on culture would henceforth be 'managed' by the central state as a pillar of pan-Canadian citizenship. For Taylor, as Canada moved further from its self-understanding as an imperial subject, this "dethroning of an Anglo-normative understanding" (2012: 417) effectively stripped citizenship of particular cultural moorings. In contrast to the main sources of contention in the British context, as highlighted above, the postnational embodiment of cultural pluralism in Canada is the policy of multiculturalism. In the absence of a substantive national identity and in response to internal nationalist mobilization, multiculturalism fills a void - elevating the status of culture to the public sphere while altogether rejecting culture as the basis for collective selfdetermination claims. Interculturalism thus emerges as an attempt by the Quebec state to re-assert an alternative understanding of the terms of belonging by forging a sort of differentiated conception of citizenship that accounts for the particular challenges of majority/minority dynamics within Quebec.

The expression of Quebec's national integration project has thus always grappled with defining the place of the majority culture, and the ambiguities, varying interpretations and distinct policy statements surrounding Quebec interculturalism over time have reflected this fundamental tension. Quebec is confronted with demarcating a community of reference and in doing so, must simultaneously affirm a constitutive status for the majority culture while embracing cultural pluralism, having rejected assimilation as morally excessive. Since its early iterations, the model has vacillated between two broad normative paradigms with regards to the place of culture. At the outset, in the early 1980s, the model emphasized a 'culture of convergence' (Government of Quebec, 1981) - signaling an initiative to reach out to minority ethnocultural groups in a period of strained relations following its referendum on secession in 1980. The model affirmed the primacy of the Quebec nation as a foyer de convergence in delineating the boundaries of integration, with the majority culture meant to serve as its "principal motor" (Labelle, 2008: 24). Critics, however, were quick to point out that a model premised on a hierarchy of cultures could easily slip into assimilationist tendencies, and in what is considered the most authoritative account of interculturalism, the government of Quebec would eventually re-conceptualize the model in 1990 around the forging of a 'common public culture' (Government of Quebec, 1990). This conceptual turn represented a more culturally neutral approach in which the majority was tasked with engaging 
in a 'moral contract' with newcomers based on reciprocal obligations - eventually leading to a more consensual 'fusion of cultures' as the basis for a referential public space. The notion of a contract was evident, members of minority cultures were expected to participate without shedding their cultural identities, through a commitment to the French language and a recognition of the majority culture, while the host society was tasked with ensuring that support and resources are made available for such ends. The result was a rejection of a pre-existing and permanent foyer of convergence and an acceptance that the terms of belonging would henceforth be negotiated through the hybridization of cultural influences, a pluralist orientation recently recommended by the Bouchard-Taylor Commission as well. ${ }^{v}$

This rather simplified account of the main orientations of Quebec interculturalism over time reveal that the elaboration of such models are anchored in the political sociology of particular national contexts. Paradoxically, Quebec interculturalism is more recognizable in Modood's account due to an acknowledged imperative to direct the model to address specific instances of non-recognition and hence inequalities within particular liberal societies that cannot escape the grip of majoritarian cultural forces. Indeed, a recent and comprehensive elaboration of interculturalism by Gérard Bouchard offers a qualification whereby the unavoidable precedence of the majority culture ought to be undertaken informally on an 'ad hoc' or contextual basis, since the primary challenge is conditioned by a duality paradigm involving the negotiation of the terms of belonging between majority and minority cultures. This notion of 'ad hoc precedence' is a distinctive attempt to marry the universal with Quebec's specificity, without recourse to a legalistic framework that would in effect create two classes of citizens. Certain concessions to the majority culture, on a case by case basis, and in a spirit of reciprocity, are not only justifiable (with a vigilant anticipation of majoritarian excess), but must remain as a defining feature of the model, since it is illegitimate to expect the very collective narrative that sustains the project for national affirmation to simply lose itself amidst a pluralist normative blueprint that fails to make substantive distinctions between politically salient collective identities. Again, it is precisely the feature of the model that accentuates the fostering of co-existence through exchange and interaction that prompts the reification of cultural identity since, in this particular sociological context, culture is the vehicle through which the national narrative is negotiated. Bouchard goes as far as to flatly affirm that social cohesion cannot be achieved unless the historical continuity provided by a majority culture is allowed to persist. This is a very different outcome of interculturalist policies than the one envisioned by Cantle, who sees in the model a means by which to transcend the grip of the 'threatened nation' and the hegemony of monistic and essentialized conceptions of collective identity that presently underpin citizenship.

Both societies are grappling with delineating the markers of belonging in a context of diversity, and interculturalism has emerged as a model that seeks to remedy a reflexive adherence to established cultural moorings by emphasizing the integrative potential of open, inclusive and reciprocal interaction among citizens negotiating a complex identity landscape. Cantle's conception of interculturalism seeks to emphasize its universal appeal, a more radical turn towards a futureoriented pluralism that strives to overcome the sorts of cultural trappings that limit the capacity for individuals and groups to fully express their identities in the public sphere. Again, in this capacity his view finds a home within Canadian multiculturalism in that both models emphasize a need to achieve a postnational citizenship space for the negotiation of shared collective identities that are not bound to particular and substantive culturalist narratives. Indeed, Canadian multiculturalism is universal in its appeal - it recognizes culture as an undifferentiated attribute that is linked to individual autonomy rather than as the basis for national integration. Writing as a Quebec scholar that has always identified interculturalism as a counterweight to undifferentiated pluralism that paradoxically weakens the political salience of culture, Modood's more nuanced appeal to consider relationships of power within particular liberal societies, contingent on sociological forces, prompts me to believe that we have indeed entered an age of interculturalism, since his eloquent defense of 
multiculturalism echoes many of the distinguishing features of Quebec's model in relation to its Canadian counterpart.

\section{References}

Bouchard G (2011) What is Interculturalism? McGill Law Journal 56(2): 435-468.

Government of Quebec (1990) Au Québec pour bâtir ensemble. Quebec City: Ministère des communautés culturelles et de l'immigration du Québec.

http://www.micc.gouv.qc.ca/publications/fr/ministere/Enonce-politique-immigration-integrationQuebec1991.pdf

Government of Quebec (1981) Autant de façons d'être Québécois. Quebec City: Ministry of Communications, Direction générale des publications gouvernementales.

Labelle M (2008) De la culture publique commune à la citoyenneté: Ancrages historiques et enjeux actuels. In Gervais S, Karmis D, Lamoureux D (eds) Du tricoté serré au métissé serré? La culture publique commune au Québec en débats. Québec: Les presses de l'Université Laval: 19-44.

Taylor C (2012) Interculturalism or Multiculturalism? Philosophy and Social Criticism 38(4-5): 413423.

\footnotetext{
' In presenting multiculturalism here I draw on Modood 2005 and 2007/2013 and do so without further referencing.

ii Also known as 'The Parekh Report', after its Chair, Lord Professor Bhikhu Parekh. Declaration of interest: I was part of the collective authorship of this report.

iii Moreover, and somewhat surprisingly, in this same period of time senior Conservatives have started to express the same view (Uberoi and Modood 2013).

${ }^{\text {iv }}$ As my example of the Rushdie affair shows the importance of dialogue has been central to multiculturalism but has been mainly thought of at the level of public discourses and political controversies. Interculturalists have added the micro in terms of interpersonal cultural encounters and group dynamics at the level of youth clubs, neighbourhoods, towns and cities (Meer and Modood, 2012).
}

\footnotetext{
'See Bouchard, G. and Taylor, C. (Co-Commissioners). 2008. Building the future, a time for reconciliation. Québec: Commission de consultation sur les pratiques d'accommodement reliées aux différences culturelles. (Abridged version)
} 